\title{
HUMOUR AS INDIRECT INFLUENCE: DIFFERENT TYPES OF MANAGERS' SENSE OF HUMOUR AND PSYCHOLOGICAL CLIMATE IN A TEAM
}

\section{SUMMARY}

Introduction. This article examines whether different levels and types of managers'sense of humour influence psychological climate in a work team.

The Aim of the Study. To investigate whether different levels out offour humour styles (affiliative, self-enhancing, aggressive, and self-defeating) and managers' sense of humour influence the psychological climate in a team of employees.

Materials and Methods. Four varieties of sense of humour were investigated: affiliative, selfenhancing, aggressive, and self-defeating as well as the aggregate multidimensional sense of humour. Multivariate analysis of variance (MANCOVA) was used with a factorial $2 x$ (gender) $x 2$ (age) $x$ 2 (humour) as independent variables and level of psychological climate (Support and Involvement scales) in work group ${ }^{l}$ as a dependent variable, and EQ interpersonal factor as covariate.

Results and Discussion. Female managers' sense of humour does not affect psychological climate in a work team indicating that the subordinates do not appreciate (or simply ignore) females'sense of humour. This conforms to the researches identifying prejudges against female managers. Some research papers state that the managers'role is perceived and explained through traits which are more often attributed to males than females. For male managers sense of humour is linked to the subordinates' willingness to be involved in work, indicating that subordinates appreciate and estimate that the manager has a sense of humour and they are more eager to take up their work roles when the supervisor is understanding and supportive. Controlling of the age factor revealed that sense of humour is important only for young male managers (those under 40); managers with a good sense of humour are perceived as supportive by the subordinates. For older managers (41 and above) no significant differences were found; that means that humour can help if a manager does not have much experience as it in the case with young managers.

Keywords: manager, psychological climate, sense of humour

\section{INTRODUCTION}

Within contemporary industrial organizations there is a growing belief that manager's sense of humour, along with other abilities, promotes effective leadership. The United States Army leadership manual describes, 'Having a good sense of humour' as a valuable character trait for leaders (Department of Army, 1983). In turn - leadership ${ }^{2}$ play important role in group regulation (Peterson, J. Behfar, 2005) and research demonstrates leadership's impact on climate in work groups (e. g., Kozlowski, Doherty, 1989; Scott, Bruce, 1994).

\footnotetext{
${ }^{1}$ Cohen and Bailey (1997) defined a work team as "a collection of individuals who are interdependent in their tasks, who share responsibility for outcomes, who see themselves and who are seen by others as an intact social entity embedded in one or more larger social systems" (p. 241).

In this research, terms work group and team are used as synonyms and exclusively to mean that member interdependence is not a necessary condition of the present model.

${ }^{2}$ In this research terms leader and manager are used as synonyms; the participants of this study were managers.
} 
Outcomes of psychological climate perceptions - satisfaction and identification with one's job and organization (e. g., James et al., 1990), positive work attitudes do generally predict absenteeism (Muchinsky, 1977), turnover (Griffith, Hom, Gaertner, 2000), citizenship (Organ, 1988), and performance (Judge, Thoreson, Bono, Patton, 2001).

So, leadership is an important factor for the psychological climate in the team. Yet how can humour be helpful in managing the work group?

\section{THE AIM OF THE STUDY}

To investigate whether different levels of managers' four humour styles (affiliative, selfenhancing, aggressive, and self-defeating) and their sense of humour influence the psychological climate in a team of employees.

\section{MATERIALS AND METHODS}

The following research questions were posed:

Are there effects of the manager's sense of humour style and sense of humour on psychological climate (managerial support and involvement)?

Research demonstrates that managers can use humour as a tool for many purposes, some - to strengthen social norms and thereby indirectly exert control over others' behaviour (Long, Graesser, 1988), to convey implicit messages in an indirect manner, to influence people to reach the team target (Mulkay, 1988), and to facilitate employees' creative thinking and problem solving (Morreall, 1991).

There are some implications how humorous people are perceived: when employees assign high rates of sense of humour to their supervisors, they also report greater job satisfaction and rate these supervisors as having generally more positive leadership characteristics (Decker, 1987).

Based on these findings, the present paper poses the question whether different levels and types of managers' sense of humour would influence psychological climate in a working team.

\section{Humour in workplace}

Humour research in the workplace is a relatively new topic that has only recently begun to be investigated (Duncan, Feisal, 1989; Duncan et al., 1990; Hatch, Ehrlich, 1993; Collinson, 2002). In the past two decades, there has been a growing interest in potential applications of humour in a variety of workplace domains. Within contemporary organizations and management there is a growing belief that jocularity is an effective vehicle to send the serious messages, and that managers' sense of humour is an important component of effective leadership (e. g., Priest, 1993).

\section{Humour and leadership}

A few studies have examined the relationship between the leader's sense of humour and his or her perceived leadership qualities (Decker, 1987). Findings suggest that supervisors with high sense of humour were rated by their supervisees as having generally more positive leadership characteristics compared to supervisors who were rated to be low in sense of humour. Employees whose supervisors had a high sense of humour also reported greater job satisfaction.

Similarly, studies in which military cadets rated the personality traits of particularly good and bad leaders found that good leaders were rated as having a significantly more warm, competent, and positive style of humour, whereas poor leaders were rated as having a more cold, inept, and mean-spirited humorous style (Priest, Swain, 2002).

In a study of the importance of humour styles for effective leadership and of gender differences therein (Decker, Rotondo, 2001), positive humour style referred to the managers' use of humour to communicate, enjoyment of jokes, and use of non-offensive humour and negative humour, sexual and insulting humour. Managers' use of positive humour was associated with more successful task and relationship behaviours and with greater overall effectiveness whereas use of negative humour was related to lower ratings on these measures of managerial competence. 
In relation to gender differences male managers were rated as using more and humour both positive and negative compared to female managers, but associations between humour and leadership competence were found to be stronger for women than for men. Women's positive humour, compared to that of men, was more strongly positively associated with leadership skills, as perceived by employees, and the use of sexual or offensive humour was more negatively related to perceived leadership in women than in men.

In regard to the negative use of humour in manager-worker communication, during staff meetings higher-status senior staff members were much more likely to use humour than were junior staff and they frequently directed their humour at junior staff in a way that conveyed a critical or corrective message (Sayre, 2001). In turn, junior staff members refrained from directing humour at senior staff, but instead tended to use it either in a self-deprecating manner or as a way of making fun of outsiders (Sayre, 2001).

Individuals who more frequently interrupted others in conversation, a behaviour that is indicative of higher status, were also more likely to engage in humour and make others laugh, even after controlling for the frequency of overall participation in group discussion. Conversely, those who were more frequently interrupted by others (reflecting their lower status) were less likely to produce humour (Robinson, Smith-Lovin, 2001).

\section{Humour as indirect influence and Leader-member exchange}

Humour research findings suggest that humour in interpersonal communication is frequently used to convey implicit messages in an indirect manner and to influence other people in various ways (Mulkay, 1988). Humour involves playing with incongruities in ideas, it conveys multiple meanings simultaneously, and is a particularly useful form of communication in situations in which a more serious and direct way runs the risk of being perceived to be confrontational. On the other hand, humour is also often used to ridicule which increases interpersonal distance.

In friendly teasing, a message of mild disapproval or censure is communicated using humour (Keltner et al., 2001). This allows the speaker to retract the message if it is not well received by saying that 'I was only joking'. Humour can be used to enforce social norms and indirectly to exert control over others' behaviour (Long, Graesser, 1988).

By using irony, teasing, sarcasm, or satire to make fun of certain attitudes, behaviours, or personality traits, members of a group can communicate implicit expectations and rules concerning the kinds of behaviour that are considered acceptable within the group. These types of humour can take the form of ridiculing members of an out-group, or they can be directed at deviant behaviours of individuals within an in-group (Martineau, 1972).

The role of humour in controlling behaviour and enforcing social norms also implies that it can be used by individuals to reinforce their own status in a group hierarchy. For example, a person is more likely to crack jokes and amuse others in a group in which he or she is the leader or has a position of dominance than in a group in which he or she has lower status and possesses less power than others. It's to match with assumption, that joking is the prerogative of those in authority (Goffman, 1961) and managers can use humorous situations 'to clarity, status and power relations' (Smeltzer, Leap, 1988, 296).

From privies we can see, that humour can be viewed as interaction between leader and follower or manager - team member. And it's important, that a supervisor is understanding and supportive, that in turn leads to higher scores on positive indicators of life quality (coping/ mastery) and lower scores on negative indicators of life quality (work/life conflict, overload, and stress) for both men and women (Moen, Yu, 2000).

Leader and coworker relationships are distinct but related factors that contribute to important organizational outcomes such as overall job satisfaction (James, James, 1989). 
Interpersonal aspects - respect, trust, and loyalty are essential components of high quality relationships at all organizational levels, among leaders and followers or among coworkers in groups or work teams (Uhl-Bien, Graen, Scandura, 2000).

Work group members experience dissatisfaction when exchanges involving these interpersonal attributes are not uniform among all members of the work group (Hiller, Day, 2003). The quality of Leader - Member Exchange (LMX) influences the nature of subordinates' relationships with one another (Sparrowe, Liden, 1997). Sherony and Green (Sherony, Green, 2002) describe how such exchanges involving leaders and coworkers may operate to maintain balance and provide empirical support for the relationship between LMX and coworker exchange.

Leader-member exchange (LMX), the most commonly used indicator of the leadersubordinate relationship, has been positively linked with various types of workplace climate, which is strongly associated with organizational culture (e. g. Cogliser, Schriesheim, 2000).

\section{Psychological Climate}

The origins of psychological climate research can be traced to Lewin et al.'s (Lewin et al., 1939) discussion of 'social climates' in the workplace.

Psychological climate refers to the shared perceptions by the members of an organization of the types of behaviours and actions that are rewarded and supported by the organization's policies, practices, and procedures (Schneider, 1990).

\section{Measures of Psychological Climate.}

Measures of psychological climate are intended to assess work environments as they are perceived and interpreted by employees (James et al., 1990).

Employees' perceptions of organizational climate are assumed to be primarily descriptive rather than affective or evaluative (Schneider, Reichers, 1983). At the individual level of analysis, referred to as 'psychological climate' (James, Jones, 1974), these perceptions represent how work environments are cognitively appraised and represented in terms of their meaning to and significance for individual employees in organizations (James, Jones, 1974; James, Sells, 1981).

Climate refers to members' shared perceptions of the types of behaviors and actions that are rewarded and supported by the organization's policies, practices, and procedures (Schneider, 1990).

Researchers have suggested that perceptions of psychological climate are associated with a variety of important outcomes at the individual, group, and organizational levels. These include leader behaviour (Rousseau, 1988; Rentsch, 1990), turnover intentions (Rousseau, 1988; Rentsch, 1990), job satisfaction (Mathieu, Hoffman, Farr, 1993; James, Tetrick, 1986; James, Jones, 1980), individual job performance (Brown, Leigh, 1996; Pritchard, Karasick, 1973), and organizational performance (Lawler et al., 1974; Patterson et al., 2004).

\section{METHOD}

\section{Participants}

A total of 267 managers (135 female, 132 male) participated in this study. Participants were divided into two age groups: Females - age 19 to $40(\mathrm{~N}=66, \mathrm{M}=31, \mathrm{SD}=6)$ and age 41 to $58(\mathrm{~N}=69, \mathrm{M}=49, \mathrm{SD}=4)$, Males - age 19 to $40(\mathrm{~N}=68, \mathrm{M}=32, \mathrm{SD}=5)$ and age 41 to 58 $(\mathrm{N}=64, \mathrm{M}=47, \mathrm{SD}=4)$.

Psychological climate data were collected from 1764 employees (approximately 3-4 from each unit).

Managers - front line managers who have subordinates (who in turn do not have subordinates).

Managers completed the measures (Humour Styles Questionnaire and Multidimensional Sense of Humour Scale) via internet. After managers had finished their task, their unit workers completed the psychological climate measure (Involvement and Supervisory Support Scales). 
Companies. The companies were located in Riga, the capital of Latvia, and were engaged in various kinds of manufacture and sales. Data were collected only from the front line units selecting only one from each organization.

\section{Measures}

Humour Styles Questionnaire (HSQ): (Martin et al., 2003). The HSQ consists of a total of 32 self-report items assessing four different styles of humour, two of which are adaptive and two of which are maladaptive. The four humour styles are:

1. Affiliative humour (adaptive other-focused) - tendency to say funny things, to tell jokes, to engage in spontaneous witty banter to amuse others, to facilitate relationships, and to reduce interpersonal tensions. "I laugh and joke a lot with my close friends";

2. Self-enhancing humour (adaptive self-focused) humorous outlook on life, a tendency to be frequently amused by the incongruities of life, and to maintain a humorous perspective even in the face of stress or adversity. "Even when I'm by myself, I am often amused by the absurdities of life";

3. Aggressive humour (maladaptive other-focused) use of sarcasm, teasing, ridicule, derision, 'put-down' or disparagement humour, which are seen as a means of enhancing oneself at the expense of one's relationships with others. "If someone makes a mistake, I will often tease them about it," and, finally

4. Self-defeating humour (maladaptive self-focused) attempts to amuse others by doing or saying funny things at one's own expense as a means of ingratiating oneself or gaining approval, allowing oneself to be the "butt" of others' humour, and using humour as a form of defensive denial. "I will often get carried away in putting myself down if it makes my family or friends laugh." Each dimension is assessed via 8 items, with each item being rated on a 7-point Likert scale that ranges from (1) "totally disagree" to (7) "totally agree".

Multidimensional Sense of Humour Scale (MSHS) (Thorson, Powell, 1993). The MSHS is a self-report scale consisting of 24 statements rated by respondents on a fivepoint Likert scale from 0 (strongly disagree) to 4 (strongly agree). Eighteen statements are positively-phrased and six are negatively-phrased to control response-set bias. The MSHS has four subscales that distinguish between 1) humour production (overt use of humour in social situations), 2) coping humour (trying to see the funny side of things), 3) humour appreciation (liking humour), and 4) humour attitude (approving of humour). In this study, the total score for MSHS was used, as well as the four factor scores obtained by summing across the items loading on each factor.

For the analysis, participants were divided into two groups, with high and low sense of humour, respectively on the basis of their HSQ and MSHS scores.

\section{Emotional intelligence}

The Bar-On EQ-i was used to assess emotional intelligence (Bar-On, 1997a). The EQ-i is a self-report measure of emotionally and socially intelligent behaviour, which provides an estimate of one's underlying emotional and social intelligence.

The EQ-i comprises 133 items and employs a five-point Likert scale with a textual response format ranging from 'very seldom or not true with me' to 'very often true with me or true with me'. A list of the inventory's items is included in the EQ-i technical manual (Bar-On, 1997b).

Factor used in research: Interpersonal EQ Interpersonal EQ consists of three subscales:

- Empathy - to be aware of and understand how others feel ('I'm unable to understand the way other people feel' "_". 
- Social responsibility - to identify with one's social group and cooperate with others ('I care what happens to other people').

- Interpersonal relationship - to establish mutually satisfying relationships and relate well with others ('It's easy for me to make friends').

In this study we use only the interpersonal factor as a covariate in the model. By doing so the effect of the managers' ability to maintain good interpersonal relationships on the psychological climate from is reduced.

Organizational Climate Measure (West, Patterson, Shackleton, Dawson, Lawthom, Maitlis, Robinson, Wallace, 2005). Questionnaire consists of a total of 82 item (17 scale), Likert scale from 1 (strongly disagree) to 5 (strongly agree). To determine psychological climate in unit is used two scales: 1) Involvement (5 point) ("Management involve people when decisions are made that affect them") and Supervisory Support scales ("Supervisors show that they have confidence in those they manage").

\section{Controlled variables}

Gender and age was controlled as these factors may influence psychological climate.

\section{Procedure}

Managers complete (via internet - online regime) Humour Styles Questionnaire, Multidimensional Sense of Humour Scale and Emotional intelligence. Managers' team members complete Organizational Climate Measure.

\section{RESULTS}

Table 2 presents the means and standard deviations found for the psychological climate (Support and Involvement scales) separately for each sense of humour (affiliative, selfenhancing, aggressive, self-defeating and multidimensional), gender and age.

The ANCOVA was used for the following reasons: first, instead of regression analysis, because our interest is to see the difference between groups (age, gender); second, with this analysis we can include a covariate variable in the model. We do ANCOVA instead of MANCOVA, because of high correlation between the dependent variable: manager support and involvement $(\mathrm{n}=258, \mathrm{r}=0.61, \mathrm{p}=0.001)$, what was tested in privies research (Roze, 2007).

The data obtained were analyzed by the means of multiple analyses of variance (ANCOVA). Respondents were divided into two groups with high and low sense of humour. A factorial design was used with 2 genders x 2 age groups (younger (age 23-40) and older (41-55)) x 2 levels of sense of humour (low and high) as independent variables and the level of psychological climate within the team as the dependent variable, and EQ Interpersonal factor as covariate. Psychological climate is aggregated by the means of the Cohen's (Cohen, Bailey, 1997) kappa coefficient from the unit members.

The test carried out in the groups (see Table 1) shows that there is a significant difference only in case of the multidimensional sense of humour. It also (see Picture 1) shows that a significant difference is only between younger managers (aged 23-40): those managers who have a better sense of humour are perceived as more supportive in comparison with young managers with a bad sense of humour $(\mathrm{p}=0.00)$.

However, the difference between the older managers is not significant, but we can see (Picture 1) that managers with a better sense of humour are perceived as more supportive in comparison with those with a bad sense of humour by work teams.

Because of covariate (EQ Interpersonal) is significant across all groups, it mean that is statistically adjusted manager's ability to maintain communication, so observed effects is comes from sense of humour its self. 
Table 1. Univariate Analysis of Variance summary table

\begin{tabular}{|c|c|c|c|c|c|c|c|c|c|c|}
\hline \multirow{3}{*}{ Factors and Variables } & \multicolumn{10}{|c|}{$\begin{array}{l}\text { Psychological Climate } \\
\end{array}$} \\
\hline & \multicolumn{5}{|c|}{ Manager support } & \multicolumn{5}{|c|}{ Involvement } \\
\hline & df & MS & $\mathbf{F}$ & $\mathbf{p}$ & eta $^{2}$ & df & MS & $\mathbf{F}$ & $\mathbf{p}$ & eta $^{2}$ \\
\hline Gender (G) & 1 & 1.97 & 0.07 & 0.80 & 0.00 & 1 & 2.51 & 0.09 & 0.77 & 0.00 \\
\hline Age & 1 & 99.89 & 3.36 & 0.07 & 0.01 & 1 & 94.68 & 3.24 & 0.07 & 0.01 \\
\hline Affiliative $\mathrm{H}$ & 1 & 21.17 & 0.71 & 0.40 & 0.00 & 1 & 2.58 & 0.09 & 0.77 & 0.00 \\
\hline Gx Age & 1 & 236.05 & 7.94 & 0.01 & 0.03 & 1 & 242.58 & 8.30 & 0.00 & 0.03 \\
\hline G x Affiliative $\mathrm{H}$ & 1 & 6.93 & 0.23 & 0.63 & 0.00 & 1 & 89.35 & 3.06 & 0.08 & 0.01 \\
\hline Age x Affiliative H & 1 & 0.27 & 0.01 & 0.92 & 0.00 & 1 & 12.81 & 0.44 & 0.51 & 0.00 \\
\hline G x Age x Affiliative H & 1 & 0.17 & 0.01 & 0.94 & 0.00 & 1 & 51.76 & 1.77 & 0.18 & 0.01 \\
\hline Covariate: EQ Interpersonal f. & 1 & 148.62 & 5.00 & 0.03 & 0.02 & 1 & 194.37 & 6.65 & 0.01 & 0.03 \\
\hline Error & 249 & 29.74 & & & & 249 & 29.24 & & & \\
\hline Gender(G) & 1 & 2.51 & 0.09 & 0.77 & 0.00 & 1 & 1.73 & 0.11 & 0.74 & 0.00 \\
\hline Age (A) & 1 & 94.68 & 3.24 & 0.07 & 0.01 & 1 & 6.12 & 0.40 & 0.53 & 0.00 \\
\hline Self-enhancing H & 1 & 2.58 & 0.09 & 0.77 & 0.00 & 1 & 5.10 & 0.33 & 0.56 & 0.00 \\
\hline $\mathrm{G} \times \mathrm{A}$ & 1 & 242.58 & 8.30 & 0.00 & 0.03 & 1 & 18.03 & 1.18 & 0.28 & 0.00 \\
\hline G x Self-enhancing H & 1 & 89.35 & 3.06 & 0.08 & 0.01 & 1 & 69.35 & 4.53 & 0.03 & 0.02 \\
\hline A x Self-enhancing H & 1 & 12.81 & 0.44 & 0.51 & 0.00 & 1 & 4.28 & 0.28 & 0.60 & 0.00 \\
\hline G x A x Self-enhancing $\mathrm{H}$ & 1 & 51.76 & 1.77 & 0.18 & 0.01 & 1 & 36.65 & 2.40 & 0.12 & 0.01 \\
\hline Covariate: EQ Interpersonal f. & 1 & 194.37 & 6.65 & 0.01 & 0.03 & 1 & 70.53 & 4.61 & 0.03 & 0.02 \\
\hline Error & 249 & 29.24 & & & & 249 & 15.30 & & & \\
\hline Gender & 1 & 3.22 & 0.11 & 0.74 & 0.00 & 1 & 0.01 & 0.00 & 0.98 & 0.00 \\
\hline Age & 1 & 93.62 & 3.16 & 0.08 & 0.01 & 1 & 14.13 & 0.91 & 0.34 & 0.00 \\
\hline Aggressive $\mathrm{H}$ & 1 & 3.21 & 0.11 & 0.74 & 0.00 & 1 & 43.26 & 2.80 & 0.10 & 0.01 \\
\hline Gender x Age & 1 & 237.69 & 8.02 & 0.01 & 0.03 & 1 & 21.15 & 1.37 & 0.24 & 0.01 \\
\hline Gender x Aggressive $\mathrm{H}$ & 1 & 44.58 & 1.50 & 0.22 & 0.01 & 1 & 17.57 & 1.14 & 0.29 & 0.00 \\
\hline Age $\mathrm{x}$ Aggressive $\mathrm{H}$ & 1 & 3.48 & 0.12 & 0.73 & 0.00 & 1 & 3.82 & 0.25 & 0.62 & 0.00 \\
\hline Gender x Age x Aggressive H & 1 & 0.82 & 0.03 & 0.87 & 0.00 & 1 & 15.87 & 1.03 & 0.31 & 0.00 \\
\hline Covariate: EQ Interpersonal & 1 & 231.65 & 7.81 & 0.01 & 0.03 & 1 & 106.30 & 6.88 & 0.01 & 0.03 \\
\hline Error & 249 & 29.64 & & & & 249 & 15.46 & & & \\
\hline Gender(G) & 1 & 3.56 & 0.12 & 0.73 & 0.00 & 1 & 0.46 & 0.03 & 0.86 & 0.00 \\
\hline Age (A) & 1 & 79.21 & 2.67 & 0.10 & 0.01 & 1 & 3.08 & 0.20 & 0.66 & 0.00 \\
\hline Self-defeating $\mathrm{H}$ & 1 & 3.55 & 0.12 & 0.73 & 0.00 & 1 & 1.03 & 0.07 & 0.80 & 0.00 \\
\hline Gender x Age & 1 & 191.10 & 6.45 & 0.01 & 0.03 & 1 & 8.73 & 0.56 & 0.45 & 0.00 \\
\hline Gx Self-defeating H & 1 & 48.15 & 1.62 & 0.20 & 0.01 & 1 & 28.77 & 1.85 & 0.18 & 0.01 \\
\hline Age x Self-defeating $\mathrm{H}$ & 1 & 5.59 & 0.19 & 0.66 & 0.00 & 1 & 0.00 & 0.00 & 1.00 & 0.00 \\
\hline Gx Ax Self-defeating $\mathrm{H}$ & 1 & 0.00 & 0.00 & 1.00 & 0.00 & 1 & 21.42 & 1.38 & 0.24 & 0.01 \\
\hline Covariate: EQ Interpersonal & 1 & 228.54 & 7.71 & 0.01 & 0.03 & 1 & 102.44 & 6.58 & 0.01 & 0.03 \\
\hline Error & 249 & 29.63 & & & & 249 & 15.56 & & & \\
\hline Gender(G) & 1 & 0.83 & 0.03 & 0.86 & 0.00 & 1 & 0.04 & 0.00 & 0.96 & 0.00 \\
\hline Age (A) & 1 & 141.42 & 4.93 & 0.03 & 0.02 & 1 & 13.81 & 0.91 & 0.34 & 0.00 \\
\hline Multidimensional Sense of Humour MS & 1 & 27.60 & 0.96 & 0.33 & 0.00 & 1 & 11.97 & 0.79 & 0.37 & 0.00 \\
\hline $\mathrm{G} \times \mathrm{A}$ & 1 & 263.79 & 9.20 & 0.00 & 0.04 & 1 & 28.65 & 1.89 & 0.17 & 0.01 \\
\hline $\mathrm{G} \times \mathrm{MS}$ & 1 & 150.38 & 5.24 & 0.02 & 0.02 & 1 & 124.08 & 8.20 & 0.00 & 0.03 \\
\hline $\mathrm{AxMS}$ & 1 & 3.81 & 0.13 & 0.72 & 0.00 & 1 & 24.32 & 1.61 & 0.21 & 0.01 \\
\hline GxAxMS & 1 & 121.29 & 4.23 & 0.04 & 0.02 & 1 & 2.83 & 0.19 & 0.67 & 0.00 \\
\hline Covariate: EQ Interpersonal f. & 1 & 121.13 & 4.22 & 0.04 & 0.02 & 1 & 44.62 & 2.95 & 0.09 & 0.01 \\
\hline Error & 249 & 28.68 & & & & 249 & 15.13 & & & \\
\hline
\end{tabular}

Key: $* \mathrm{p}<.05 ; * * \mathrm{p}<.01 ; * * * \mathrm{p}<.001$ 


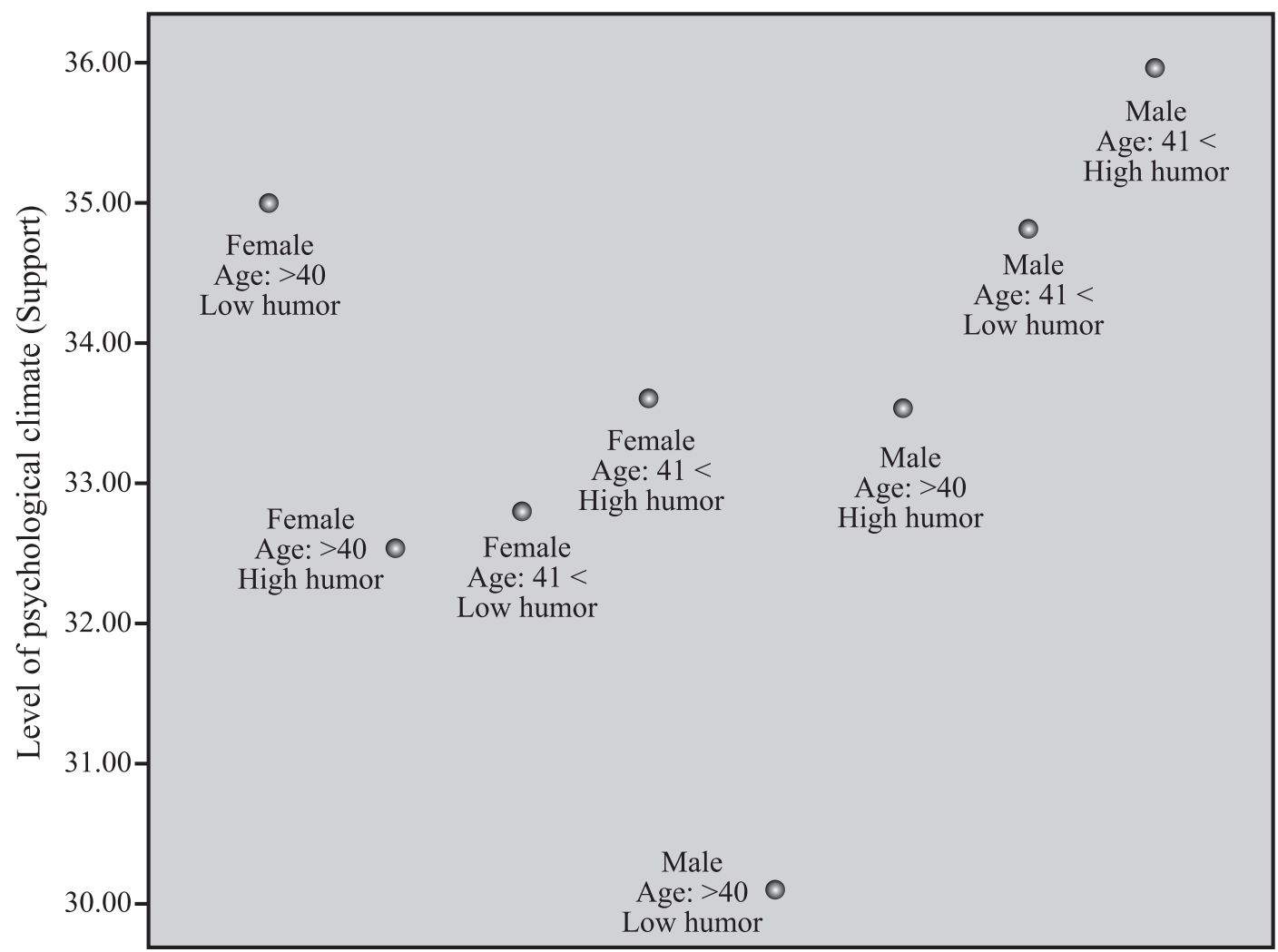

\section{DISCUSSION}

The aim of this study is to investigate whether different levels of managers' four humour styles (affiliative, self-enhancing, aggressive, and self-defeating) and multidimensional sense of humour have an influence on the psychological climate in the work unit - this hypothesis is partly confirmed. A multi-source approach generally leads to lower correlations and effects, compared to correlations and effects between two constructs originating from the same source. In this research two sources were used: psychological climate as perceived by the managers (sense of humour, Interpersonal factor) and subordinates.

This research provides evidence that manager's sense of humour have effect on perceived managerial support even when statistically adjusted in maintaining communication (by controlling EQ Interpersonal factor), but it is true only for male managers.

This research finding is supported with another - importance of sense of humour styles for effective leadership (e. g., Decker, Rotondo, 2001) and leadership has conducted to psychological climate (Dragoni, 2005) for female managers no association between sense of humour and psychological climate, however males have. This finding can lead to conclusion that is in society and supported of same scholars (e. g., McGhee, 1979; Pollio, Edgerly, 1976) that males more cracking jokes and in general use more humour in communication. But from other side - possible, that subordinates do not appreciate (or just ignore) females sense of humour, that can be explained with researches focused on prejudges. For example, some research show, that manager's role perceived and explained by traits 
Table 2. Mean and Standard Deviation number of humour (Affiliative, Self-enhancing, Aggressive humour, Self-defeating and Multidimensional) Psychological climate (support and involvement scales)

\begin{tabular}{|c|c|c|c|c|c|c|c|c|}
\hline \multirow{3}{*}{$\begin{array}{l}\text { Humour } \\
\text { type }\end{array}$} & \multirow{3}{*}{ Gender } & \multirow{3}{*}{ Age } & \multirow{3}{*}{$\mathbf{N}$} & \multirow{3}{*}{$\begin{array}{l}\text { Level of } \\
\text { humour }\end{array}$} & \multicolumn{4}{|c|}{ Psychological climate } \\
\hline & & & & & \multicolumn{2}{|c|}{ Involvement } & \multicolumn{2}{|c|}{ Support } \\
\hline & & & & & M & SD & M & SD \\
\hline \multirow{8}{*}{ 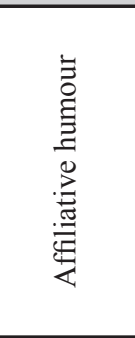 } & \multirow{4}{*}{ Female } & \multirow{2}{*}{$25-40$} & 31 & Low & 30.76 & 3.04 & 33.58 & 5.08 \\
\hline & & & 35 & High & 30.59 & 3.32 & 34.57 & 5.25 \\
\hline & & \multirow{2}{*}{$41-55$} & 38 & Low & 30.79 & 4.54 & 32.94 & 7.06 \\
\hline & & & 31 & High & 29.88 & 3.85 & 33.74 & 5.41 \\
\hline & \multirow{4}{*}{ Male } & \multirow{2}{*}{$25-40$} & 25 & Low & 28.62 & 4.73 & 30.93 & 6.35 \\
\hline & & & 37 & High & 30.96 & 3.67 & 32.68 & 5.22 \\
\hline & & \multirow{2}{*}{$41-55$} & 31 & Low & 30.13 & 4.50 & 34.40 & 5.07 \\
\hline & & & 30 & High & 31.61 & 3.71 & 35.97 & 3.74 \\
\hline \multirow{8}{*}{ 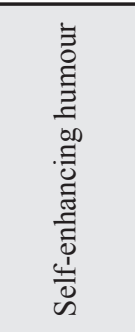 } & \multirow{4}{*}{ Female } & \multirow{2}{*}{$25-40$} & 31 & Low & 30.31 & 3.49 & 34.50 & 4.88 \\
\hline & & & 35 & High & 30.99 & 2.87 & 33.76 & 5.44 \\
\hline & & \multirow{2}{*}{$41-55$} & 38 & Low & 31.07 & 3.38 & 33.26 & 6.26 \\
\hline & & & 31 & High & 29.67 & 4.92 & 33.34 & 6.51 \\
\hline & \multirow{4}{*}{ Male } & \multirow{2}{*}{$25-40$} & 25 & Low & 29.37 & 4.77 & 30.19 & 6.32 \\
\hline & & & 37 & High & 30.58 & 3.72 & 33.54 & 4.68 \\
\hline & & \multirow{2}{*}{$41-55$} & 31 & Low & 29.79 & 4.48 & 34.83 & 4.98 \\
\hline & & & 30 & High & 32.03 & 3.49 & 35.55 & 3.95 \\
\hline \multirow{8}{*}{ 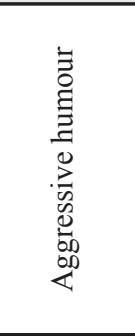 } & & & 31 & Low & 30.67 & 3.39 & 34.65 & 4.14 \\
\hline & & $25-40$ & 35 & High & 30.67 & 3.00 & 33.60 & 5.97 \\
\hline & Female & $41-55$ & 38 & Low & 30.33 & 4.24 & 33.60 & 6.17 \\
\hline & & $41-55$ & 31 & High & 30.47 & 4.34 & 32.70 & 6.75 \\
\hline & & & 25 & Low & 28.66 & 4.44 & 31.40 & 5.73 \\
\hline & Male & $25-40$ & 37 & High & 30.76 & 4.01 & 32.29 & 5.75 \\
\hline & Male & & 31 & Low & 30.68 & 3.97 & 34.77 & 4.15 \\
\hline & & $41-55$ & 30 & High & 31.04 & 4.41 & 35.59 & 4.87 \\
\hline & & $25-40$ & 31 & Low & 30.59 & 3.37 & 34.43 & 4.83 \\
\hline 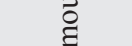 & & $25-40$ & 35 & High & 30.77 & 2.96 & 33.72 & 5.58 \\
\hline 豆 & remale & $41-55$ & 38 & Low & 30.82 & 3.60 & 33.21 & 7.25 \\
\hline$\stackrel{00}{\Xi}$ & & $41-55$ & 31 & High & 30.02 & 4.72 & 33.37 & 5.59 \\
\hline हु & & & 25 & Low & 29.82 & 4.94 & 31.48 & 6.25 \\
\hline$\frac{\pi}{0}$ & Male & $25-40$ & 37 & High & 30.26 & 3.24 & 32.61 & 4.98 \\
\hline$\frac{ \pm}{0}$ & Male & $41-55$ & 31 & Low & 30.00 & 4.93 & 34.30 & 4.71 \\
\hline & & $41-55$ & 30 & High & 31.41 & 3.54 & 35.74 & 4.33 \\
\hline & & $25-40$ & 31 & Low & 30.57 & 3.30 & 34.95 & 4.01 \\
\hline త్రే & & $25-40$ & 35 & High & 30.80 & 3.06 & 33.03 & 6.24 \\
\hline 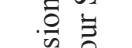 & Female & 41 & 38 & Low & 31.14 & 2.90 & 32.67 & 6.83 \\
\hline 巳ี ఏ & & $41-$ & 31 & High & 29.64 & 5.17 & 33.92 & 5.86 \\
\hline 句急 & & & 25 & Low & 28.29 & 4.74 & 29.37 & 6.27 \\
\hline 严 & Male & $25-40$ & 37 & High & 31.10 & 3.57 & 33.62 & 4.72 \\
\hline$\sum \tilde{u}_{0}$ & Male & & 31 & Low & 30.05 & 4.21 & 34.39 & 4.82 \\
\hline & & $41-55$ & 30 & High & 31.95 & 3.92 & 36.22 & 3.87 \\
\hline
\end{tabular}


which is closer to males, then females (Eagly, Karau, 2002; Garcia-Retamero, Lopez-Zafra, 2002). Males concentrate on roles in which can express authority, power and domination. From that come some effects - male manager is perceived as more authoritative, what in tern gives to males more influence on group (unit), compare with female managers (Carli, 2001; Rudman, Kilinski, 2000). So, possible, when subordinates communicate with their female manager they do not much judge female manager abilities that reviled in meta-analytical research (Eagly et al., 1992) and probably do not communication and humour abilities what in this research they judge themselves.

For male managers sense of humour is linked to the subordinates' willingness to be involved in work, indicating that subordinates appreciate and estimate that the manager has a sense of humour and they are more eager to take up their work roles when the supervisor is understanding and supportive. That in turn leads to higher scores on positive indicators of life quality (Moen, Yu, 2000), and employees have greater job satisfaction (Decker, 1987).

\section{CONCLUSIONS}

This research is quite innovative; in comparing privies the factorial design has been used - the factors of gender and age have been controlled in order to better understand the nature of humour.

Humour plays an important role in the human behaviour and especially in interaction. This quantitative research shows the importance of using humour in management, however, it also points out the factors that must be controlled: if we focus on humour research in communication the interpersonal factor has to be controlled.

\section{LIMITATION OF RESEARCH}

To measure managers' sense of humour self-report inventory was used in the research, however, a more appropriate tool might be the poll how managers' sense of humour is perceived by their subordinates.

Also, most team are mixed as to the employee sexes; it is possible that homogenous groups (males or females exclusively) would rate their managers differently.

\section{Further research directions}

In further research it is necessary to select four types of employee groups: male subordinates who would rate a female manager and vice versa; female subordinates rating a female manager and vice versa. Thus, in future researches it is necessary not only to control the factors related to the managers' sex and age but also that of the employee teams'.

\section{REFERENCES}

1. Brown, S., Leigh, T. W. (1996) A New Look at Psychological Climate and Its Relationship to Job Involvement, Effort, and Performance. Journal of Applied Psychology, No 81, p. 358-368.

2. Cogliser, C. C., Schriesheim, C. A. (2000) Exploring Work Unit Context and Leader-Member Exchange: A Multi-Level Perspective. Journal of Organizational Behavior, No 21, p. 487-511.

3. Cohen, S. G., Bailey, D. E. (1997) What Makes Teams Work: Group Effectiveness Research from the Shop Floor to the Executive Suite. Journal of Management, No 23, p. 239-290.

4. Collinson, D. L. (2002) Managing Humour. Journal of Management Studies, May, Vol. 39, Issue 3, p. 269-302.

5. Decker, W. H., Rotondo, D. M. (2001) Relationships among Gender, Type of Humour, and Perceived Leader Effectiveness. Journal of Managerial Issues, 13(4), p. 450-465.

6. Department of the Army (1983) FM22-100: Military Leadership.

7. Dragoni, L. (2005) Understanding the Emergence of State Goal Orientation in Organizational Work Groups: The Role of Leadership and Multi-Level Climate Perceptions. Journal of Applied Psychology, No 90, p. 1084-1095. 
8. Duncan, W. J., Feisal, J. P. (1989) No Laughing Matter: Patterns of Humour in the Workplace. Organizational Dynamics, 17(4), p. 18-30.

9. Duncan, W. J., Smeltzer, L. R., Leap, T. L. (1990) Humour and Work: Applications of Joking Behavior to Management. Journal of Management, 16(2), p. 255-278.

10. Goffman, E. (1961) Encounters. Harmondsworth: Penguin, 450 p.

11. Griffith, R. W., Hom, P. W., Gaertner, S. (2000) A Meta-Analysis of Antecedents and Correlates of Employee Turnover: Update, Moderator Tests, and Research Implications for the Next Millennium. Journal of Management, No 26, p. 463-88.

12. Hatch, M. J., Ehrlich, S. B. (1993) Spontaneous Humour as an Indicator of Paradox and Ambiguity in Organizations. Organization Studies, 14(4), p. 505-526.

13. Hiller, N. J., Day, D. V. (2003) LMX and Teamwork: The Challenges and Opportunities of Diversity. In: G. B. Graen (Ed.), Dealing with Diversity. Greenwich: Information Age Publishing, p. 29-57.

14. James, L. R., James, L. A., Ashe, D. K. (1990) The Meaning of Organizations: the Role of Cognition and Values. In: B. Schneider (Ed.), Organizational climate and culture. San Erancisco, CA: Jossey-Bass. p. 335.

15. James, L. R., Jones, A. P. (1974) Organizational Climate: a Review of Theory and Research. Psychological Bulletin, 81, p. 1096-1112.

16. James, L. R., Jones, A. P. (1980) Perceived Job Characteristics and Job Satisfaction: an Examination of Reciprocal Causation. Personnel Psychology, 33, p. 97-135.

17. James, L. R., Sells, S. B. (1981) Psychological Climate: Theoretical Perspectives and Empirical Research. In: D. Magnusson (Ed.) Toward a Psychology of Situations: An Interactional Perspective. Hillsdale, NJ: Erlbaum, p. 275-292.

18. James, L. R., Tetrick, L. E. (1986) Confirmatory Analytic Tests of three Causal Models Relating Job Perceptions to Job Satisfaction. Journal of Applied Psychology, 71, p. 77-82.

19. Judge, T. A., Thoreson, C., Bono, J. E., Patton, G. K. (2001) The Job Satisfaction-Job Performance Relationsbip: a Qualitative and Quantitative Review. Psychological Bulletin. 127, p. 376-407.

20. Keltner, D., Capps, L., Kring, A. M., Young, R. C., Heerey, E. A. (2001) Just Teasing: A Conceptual Analysis and Empirical Review. Psychological Bulletin, 127(2), p. 229-248.

21. Kozlowski, S. W. J., Doherty, M. L. (1989) Integration of Climate and Leadership: Examination of a Neglected Issue. Journal of Applied Psychology, 74, p. 546-553.

22. Lawler, E. E., Hall, D. T., Oldham, G. R. (1974) Organizational Climate: Relationship to Organizational Structure, Process and Performance. Organizational Behavior and Performance, 11, p. 139-155.

23. Long, D. L., Graesser, A. C. (1988) Wit and Humour in Discourse Processing. Discourse Processes, 11(1), p. 35-60.

24. Martin, R. A., Puhlik-Doris, P., Larsen, G., Gray, J., Weir, K. (2003) Individual Differences in Uses of Humour and Their Relation to Psychological Well-Being: Development of the Humour Styles Questionnaire. Journal of Research in Personality, 37, p. 48-75.

25. Martineau, W. H. (1972) A Model of the Social Functions of Humour. In: J. H. Goldstein, P. E. McGhee (Eds.) The Psychology of Humour: Theoretical Perspectives and Empirical Issues. New York: Academic Press, p. 101-125.

26. Mathieu, J. E., Hoffman, D. A., Farr, J. L. (1993) Job Perceptions-Job Satisfaction Relations: an Empirical Comparison of Three Competing Theories. Organizational Behavior and Human Decision Processes, 56, p. 370-387.

27. Moen, P., Yu, Y. (2000) Effective Work/Life Strategies: Working Couples, Work Conditions, Gender, and Life Quality. Social Problems, 47, p. 291-326.

28. Morreall, J. (1991) Humour and Work. Humour: International Journal of Humour Research, 4(3-4), p. 359-373.

29. Muchinsky, P. M. (1977) Organizational Communication: Relationships to Organizational Climate and Job Satisfaction. Academy of Management Journal, 20, p. 592-607.

30. Mulkay, M. (1988) On Humour: Its Nature and its Place in Modern Society. New York: Basil Blackwell, 267 p. 
31. Organ, D. C. (1988) Organizational Citizenship Behavior: The Good Soldier Syndrome. Lexington, MA: Lexington Books, $237 \mathrm{p}$.

32. Patterson, M. G., Warr, P. B., West, M. A. (2004) Organizational Climate and Company Performance: the Role of Employee Affect and Employee Level. Journal of Occupational and Organizational Psychology, 77, p. 193-216.

33. Peterson, R. S., Behfar, K. J. 2005. Leadership as Group Regulation. In: D. M. Messick, R. M. Kramer (Eds.), The Psychology of Leadership: New Perspectives and Research. Mahwah, NJ: Lawrence Erlbaum, p. 143-162.

34. Priest, R. F., Swain, J. E. (2002) Humour and Its Implications for Leadership Effectiveness. Humour: International Journal of Humour Research, 15(2), p. 169-189.

35. Pritchard, R. D., Karasick, B. W. (1973) The Effects of Organizational Climate on Managerial Job Performance and Satisfaction. Organizational Behavior and Human Performance, 9, p. 126-146.

36. Rentsch, J. (1990) Climate and Culture: Interaction and Qualitative Differences in Organizational Meanings. Journal of Applied Psychology, 75, p. 668-681.

37. Robinson, D. T., Smith-Lovin, L. (2001) Getting a Laugh: Gender, Status, and Humour in Task Discussions. Social Forces, 80(1), p. 123-158.

38. Rousseau, D. M. (1988) The Construction of Climate in Organizational Research. In: C. L. Cooper, I. T. Robertson (Eds.) International Review of Industrial and Organizational Psychology, 3. New York: Wiley, p. 139-158.

39. Roze, J. (2007) Relation between Styles of Humour and Emotional Intelligence. Presentation on 13th European Conference on Developmental Psychology, Jena, Germany, 21.-25.08.2007.

40. Sayre, J. (2001) The Use of Aberrant Medical Humour by Psychiatric Unit Staff. Issues in Mental Health Nursing, 22(7), p. 669-689.

41. Schneider, B. (1990) The Climate for Service: An Application of the Climate Construct. In: B. Schneider (Ed.) Organizational Climate and Culture. San Francisco: Jossey-Bass, p. 383-409.

42. Schneider, B., Reichers, A. E. (1983) On the Etiology of Climates. Personnel Psychology, 36, p. 19-39.

43. Scott, S. G., Bruce, R. A. (1994) Determinants of Innovative Behavior: A Path Model of Individual Innovation in the Workplace. Academy of Management Journal, 37, p. 580-608.

44. Sherony, K. M., Green, S. G. (2002) Coworker Exchange: Relationships between Coworkers, LeaderMember Exchange, and Work Attitudes. Journal of Applied Psychology, 87, p. 542-548.

45. Smeltzer, L. R., Leap, T. L. (1988) An Analysis of Individual Reactions to Potentially Offensive Jokes in Work Settings. Human Relations, 41, p. 295-304.

46. Sparrowe, R. T., Liden, R. C. (1997) Process and Structure in Leader-Member Exchange. Academy of Management Review, 22, p. 522-552.

47. Thorson, J. A., Powell, F. C. (1993) Development and Validation of a Multidimensional Sense of Humour Scale. Journal of Clinical Psychology, 49, p. 13-23.

48. Uhl-Bien, M., Graen, G. B., Scandura, T. A. (2000) Implications of Leader-Member Exchange (LMX) for Strategic Human Resource Management Systems: Relationships as Social Capital for Competitive Advantage. In: G. R. Ferris (Ed.) Research in Personnel and Human Resources Management. Vol. 18, Greenwich, CT: JAI Press, p. 137-185.

49. Yip, J. A., Martin, R. A., (2006) Sense of Humour, Emotional Intelligence, and Social Competence. Journal of Research in Personality, 40, 6, p. 1202-1208.

Lecture Mg. psych. Jānis Roze

Riga Teacher Training and Educational Management Academy

Address: Imantas 7. linija 1, Riga, LV - 1083

Mob. phone: + 37126762686

E-mail: janis_roze08@inbox.lv 